\title{
Effect of inorganic nitrogen concentration in co-culture and regeneration media on Agrobacterium tumefaciens growth and on the regenerative capacity of transformed Pinus radiata embryonal mass
}

\author{
Regis Le-Feuvre ${ }^{1 *}$, Claudia Triviño², Ana María Sabja ${ }^{2}$, Krystyna Klimaszewska $^{3}$ \\ From IUFRO Tree Biotechnology Conference 2011: From Genomes to Integration and Delivery \\ Arraial d'Ajuda, Bahia, Brazil. 26 June - 2 July 2011
}

The Genetic Engineering program at Genomica Forestal SA, Chile (GFSA) has a goal of generating stably transformed radiata pine for in planta evaluation of candidate genes. Regeneration of transgenic plants depends mainly on two factors: regeneration ability of transformed cells and stable transgene integration and expression.

In several conifer species, including radiata pine, transgenics have been regenerated through cocultivation of Agrobacterium tumefaciens with embryogenic cells [1-3]. However, in our first experiments using MSG [4] culture medium we found that radiata pine embryonal masses did not recover easily after co cultivation and that there was an excessive overgrowth of bacterial cells in spite of using bacteriostatics in the medium. This impediment prompted our study on testing other culture medium formulations, routinely used in conifer somatic embryogenesis, on the growth of $A$. tumefaciens GV3101. The tested media were: MSG, DCR [5], and modified Litvay [6] MLV. Of the three media MSG supported significantly higher bacterial growth than the other two media. One of the major differences in the composition of these media is inorganic nitrogen concentration $\left(\mathrm{NH}_{4} \mathrm{NO}_{3}\right.$ and $\left.\mathrm{KNO}_{3}\right)$. Compared with MLV and DCR, MSG has the lowest concentration of inorganic nitrogen $\left(100 \mathrm{mgl}^{-1}\right.$ compared with 340 in DCR and $950 \mathrm{mgl}^{-1}$ in MLV) provided in the sole form of

\footnotetext{
* Correspondence: rlefeuvre@gfsachile.cl

${ }^{1}$ Genomica Forestal S.A., CBT Universidad de Concepción, Concepción, Chile Full list of author information is available at the end of the article
}

$\mathrm{KNO}_{3}$. Based on our results and the work of others, we concluded that low nitrate concentration in MSG medium promoted $A$. tumefaciens growth and this had a deleterious influence on the viability of radiata pine cells during co cultivation, and also rendered eradication of bacterial cells difficult. Comparison of growth of radiata pine embryonal mass on the three media did not show statistically significant differences. A strategy for producing transgenic radiata pine for in planta transgene expression and stability study will be presented.

\footnotetext{
Author details

'Genomica Forestal S.A., CBT Universidad de Concepción, Concepción, Chile. ${ }^{2}$ Genfor S.A., Fundación Chile, sucursal Valdivia, Valdivia, Chile. ${ }^{3}$ Natural Resources Canada, Canadian Forest Service, Laurentian Forestry Centre, 1055 du P.E.P.S., Quebec, QC G1V 4C7, Canada.

Published: 13 September 2011

\section{References}

1. Levée V, Lelu M, Jouanin L, Cornu D, Pilate G: Agrobacterium tumefaciensmediated transformation of hybrid larch (Larix kaempferi $x$ L. deciduas) and transgenic plant regeneration. Plant Cell Reports 1997, 16:680-685.

2. Klimaszewska K, Park Y, Overton C, MacEacheron I, Bonga J: Optimized somatic embryogenesis in Pinus strobes L. In vitro Cell Dev. Biol 2001, 37:392-399.

3. Grace L, Charity J, Gresham B, Kay N, Walter C: Insect-resistant transgenic Pinus radiata. Plant Cell Reports 2005, 24:103-111.

4. Beckwar M, Nagmani R, Wann S: Initiation of embryogenic cultures and somatic embryo development in loblolly pine (Pinus taeda). Can. J. For. Res 1990, 20:810-817.

5. Gupta P, Durzan D: Shoot multiplication for mature trees of Douglas fir (Pseudotsuga menziesii) and sugar pine (Pinus lambertiana). Plant Cel. Rep 1985, 4:177-179.
} 
6. Litvay J, Verma D, Johnson M: Influence of a loblolly pine (Pinus taeda L.) culture medium and its components on growth and somatic embryogenesis of the wild carrot (Daucus carrot L:). Plant Cell. Rep 1985, 4:325-328.

doi:10.1186/1753-6561-5-S7-P141

Cite this article as: Le-Feuvre et al.: Effect of inorganic nitrogen concentration in co-culture and regeneration media on Agrobacterium tumefaciens growth and on the regenerative capacity of transformed Pinus radiata embryonal mass. BMC Proceedings 2011 5(Suppl 7):P141.

Submit your next manuscript to BioMed Central and take full advantage of:

- Convenient online submission

- Thorough peer review

- No space constraints or color figure charges

- Immediate publication on acceptance

- Inclusion in PubMed, CAS, Scopus and Google Scholar

- Research which is freely available for redistribution

Submit your manuscript at www.biomedcentral.com/submit
() Biomed Central 